to south between Hunstanton and Mildenhall, and continuing south-west by Newmarket towards Royston.

The intensely chalky boulder clay of the Cromer district $^{3}$, on the other hand, can belong to the Lower Chalky glaciation, because ice from the north-west in northern Norfolk would have passed along the strike of the Lincolnshire chalk.

Apart from the matrix of the boulder clays, these ice-directions are confirmed by such erratics as have been collected in situ in the boulder clays. The Lower Chalky at Claydon, near Ipswich, contained flint, hard chalk, Neocomian sandstone, Red 'Chalk' (very rare, and doubtfully in situ), Septaria, Kimmeridge Shale, Oolite (probably from Lincolnshire), Gryphoea cf. incurva, Bunter quartzites, blue limestones (? Carboniferous or Jurassic), ? Millstone Grit and non-porphyritic basalts (which may be from Derbyshire). At Bawsey, east of King's Lynn, collection included flint, hard chalk, Neocomian Sandstone, Terebratula cf. rosenkranzi and Pavlovia cf. worthensis (Portlandian), and possibly Bunter pebbles. The same boulder clay at Pakefield, near Lowestoft, yielded similar Cretaceous and Jurassic rocks, including Ostrea dilatata, Ostrea delta and Pachyteuthis abbreviata. The Lower Lias is probably represented by Lima hermanni. The Lowestoft boulder clay also contains Bunter quartzites, blue limestone (? Carboniferous), basalt and a small rounded pebble of schist. This last erratic is probably derived from the underlying Corton Beds. If the long list of Jurassic fossils from Ormsby St. Margaret, published in the Geological Survey Memoir (Yarmouth), is taken into account, the Lower Chalky Boulder Clay is seen to consist of Cretaceous, Jurassic, Trias and probably Carboniferous pebbles in a matrix of various Jurassic clays. No other igneous or metamorphic erratics were found in situ. This boulder clay appears to be the product of Pennine Ice, which has travelled southeast across mainly Jurassic outerops.

The Upper Chalky Boulder Clay is consistently different. Cretaceous material is much more common than Jurassic. Red 'Chalk' is abundant, especially at Claydon and Bolton's pits near Ipswich, also blueand-white flint with the so-called 'basket-work' patina, which is not known to occur in the Lower Chalky. The Upper Chalky also contains Bunter pebbles, porphyrites of supposed Old Red Sandstone type, ? volcanic tuff, various felspathic grits and a sandstone with abundant tourmaline (at Hoxne). An erratic of rhomb-porphyry was found some years ago by Miss Tomlinson close to Upper Chalky Boulder Clay in Bolton's pit, Ipswich. Such Jurassic fossils as occur rarely could be derived from the Lower Chalky Boulder Clay. The Upper Chalky is therefore a deposit containing much flint, and erratics from apparent Scottish Old Red Sandstone, with others which could be derived from one of the Cromer Tills, in a matrix of sand and soft chalk. It appears to represent Scottish Ice, which has entered west Norfolk and Suffolk from a northerly direction off the existing Lincolnshire coast.

These two boulder clays are not often seen in direct superposition, but they are exposed together in the pit at Claydon, and have been seen in former sections at Hoxne and Derby Road brickworks at Ipswich (where the Upper Chalky is decalcified), at Bolton's pit, and probably elsewhere. Most of the Acheulean and associated implements of the Ipswich district come from interglacial deposits between these two boulder clays.
The marine March Gravels of the Fenland have been described as resting on a chalky boulder clay, and it is obviously not possible that the chalky boulder clay at Peterborough, for example, was laid down by ice crossing the oolitic rocks from the northwest. The chalky boulder clay of Fenland contains Cretaceous material from Lincolnshire, local Jurassic septaria, felspathic grit, and schists and gneisses which could be derived from Cromer Till, in a matrix of local Jurassic clays. This assemblage, especially in southern and western Fenland, points to ice-movement from the north across the Lincolnshire Wolds. This direction is parallel to that of the Upper Chalky of West Suffolk, and the Fenland boulder clay is most easily accounted for as having been brought by the Upper Chalky Ice. It should be emphasized that it is different in many ways from the Hessle Boulder Clay of the Fens, which in any case overlies the March Gravels.

If this explanation of the chalky boulder clays is correct, correlation becomes possible between East Anglia and a large area of the East Midlands. Deeley? Boswell ${ }^{1}$ and Hollingworth ${ }^{8}$ have shown that the early Pennine Boulder Clay of the East Midlands underlies later chalky boulder clay from the northeast, and many of the relevant memoirs of the Geological Survey admit a similar sequence. The simplest explanation of these facts is that the older Pennine Ice from Derbyshire to the Fens was the same as that which deposited the Lower Chalky Boulder Clay of East Anglia : and that the younger ice which brought Cretaceous and other material from the north-east to the districts round the Trent, the Stratford Avon and the neighbourhood of Bucking. ham, was contemporaneous with that which deposited the Upper Chalky Boulder Clay of Suffolk. This hypothesis fits the facts better than Harmer's conception of a single ice-sheet with its fanning-out and cross-currents.

It is hoped to publish the full evidence on which this work is based as soon as possible. The boulder clay samples are still being worked out in detail. I would like to thank Dr. W. J. Arkell for identifying many of the Jurassic fossils.

1 Boswell, P. G. H., Proc. Geol. Assoc., 42, 87 (1931).

Solomon, J., Proc. Geol. Assoc., 43. 244 (1932).

3 Baden-Powell, D. F. W., and Moir, J. R., Geol. Maq., 79, 210 (1942).

- Paterson, T. T., and Fagg, B. E. B., Proc. Prehist. Soc., 6, 4 (1940).

' Harmer, F. W., Proc. Yorks. Geol. Soc., 21, 88 (1928).

- Baden-Powell, D. F. W., Geol. Mag., 71, 215 (1934).

${ }^{7}$ Deeley, R. M., Quart. J. Geol. Soc., 42, 439 (1886).

${ }^{8}$ Hollingworth, S. E., and Taylor, J. H., Proc. Geol. Assoc., 57, 230 (1946).

\section{AMALGAMATION OF SOME ALLOYS OF GOLD, SILVER AND COPPER}

\section{By DR. DOUGLAS RENNIE HUDSON University of Leeds}

7 HE surface of amalgamated metals is greasy to touch, and lustrous in appearance like liquid mercury. In a previous publication ${ }^{1}$ the extreme tenuity $\left(2 \cdot 7 \times 10^{-4} \mathrm{~cm}\right.$.) of the film necessary to confer these properties on a pure silver surface was noted. This observation has been confirmed for goldrich alloys of the legalized carat compositions used for jewellery, for some silver alloys, and for bronzes. By the nature of the problem, exactly reproducible 
results could scarcely be expected, but, in fact, surprisingly concordant values have been obtained. The problem is of interest in the amalgamation of coarse gold concentrates from the corduroy table on the Rand ${ }^{2}$.

Gold-rich alloys. Values of the equivalent film thickness in the hard-rolled state are too erratic to be compared, since in this condition the alloys crumble on mere contact with liquid mercury. This is the phenomenon of 'season cracking' attributed to intercrystalline penetration of the strained metal by liquid mercury.

In the rolled state (half-hard, with 'close' surface texture), the equivalent thickness of mercury is a little more than $1 \times 10^{-4} \mathrm{~cm}$. On fully annealing the gold alloys in hydrogen, giving a surface with 'open' texture, this thickness rises somewhat, attaining a value less than $2 \times 10^{-4} \mathrm{~cm}$.

After polishing the half-hard alloys to a 000 emery finish, the equivalent thickness is reduced to about a third. In annealed alloys similarly polished the equivalent thickness is very slightly less. The polishing appears to activate the surface and renders it very able to take up the mercury; a similar procedure may be adopted to bring annealed metals into a state of standard strain for electrode potential determinations.

Comparison tests on a few commercial golds showed a wide variation in the thickness of the equivalent layer, namely, $0 \cdot 45-2 \cdot 7 \times 10^{-4} \mathrm{~cm}$. This is attributed to wide differences in the surface texture, polish, roughness and hardness. (A smooth surface may have an 'open' texture ${ }^{3}$.) In all cases burnished surfaces yielded thin films. 18-ct. 'white gold' was particularly difficult to amalgamate. 'Rolled' gold gave the low value of $0.22 \times 10^{-4}$.

Silver alloys. In silver alloys the effect of surface roughness is shown by the equivalent thickness of more than $3 \times 10^{-4} \mathrm{~cm}$. on the plated pure silver surface of a new shilling, compared with $27 \times 10^{-4}$ $\mathrm{cm}$. for pure silver and $0.6 \times 10^{-4} \mathrm{~cm}$. for the underlying basis metal containing only 50 per cent silver, when polished to a 000 emery finish. A similarly prepared surface on sterling silver $(92.5$ per cent) gave $0.6 \times 10^{-4} \mathrm{~cm}$.

On standing for a few hours, the lustrous surface becomes mat. This is not due, as might be suggested, to diffusion of mercury atoms into the silver crystals, and subsequent fixation as a result of synthesis ${ }^{4}$ of $\mathrm{Ag}_{3} \mathrm{Hg}_{4}$. This process is much slower, and may take weeks, whereas the lustre of the mat surface can be restored by gentle rubbing. Probably it is due to thixotropic setting within the surface layer of mercury ${ }^{5}$.

Copper alloys. Most gold and silver alloys amalgamate readily on mere contact with mercury, and the wetted area extends quickly on gentle rubbing. But copper and its alloys are difficult to amalgamate by contact, even when surface cleanliness is not in question. Prolonged rubbing is necessary, and it is not surprising that resulting films are much thicker, as much as $14 \times 10^{-4} \mathrm{~cm}$. having been observed. However, they do not seem to differ in behaviour from amalgamated alloys of gold and silver. This difficulty in wetting is quite consistent with immediate formation in air of a thin invisible oxide film on newly polished copper surfaces, which has been deduced from electron diffraction and surface reflectivity measurements. Chemical amalgamation yields much thinner films; about $1.4 \times 10^{-4} \mathrm{~cm}$. by displacement in mercurous nitrate solution, and about half that thickness in a mixture of mercury and nitric acid. This also is consistent with the shielding effect of an oxide layer.

Phosphor bronze, and copper alloyed with a little beryllium (so-called beryllium bronze) closely resembling it in physical properties, both gave surprisingly low thickness for contact amalgamation of surfaces polished to a 000 emery finish, respectively 0.07 and $0.1 \times 10^{-4} \mathrm{~cm}$. Values obtained by chemical amalgamation, while still small at $0 \cdot 12-0 \cdot 19 \times 10^{-4}$ $\mathrm{cm}$. and $0.35-1.6 \times 10^{-4} \mathrm{~cm}$., much exceeded the contact values. It is clear that surface conditions are very important in the amalgamation of copper alloys.

Grateful acknowledgment is made to the Carnegie Trust, which supplied the precious metals, and particularly to its secretary, Dr. Peddie.

${ }^{1}$ Hudson, D. R., Metallurgin, 29, 299 (1944).

Year Book of the Union of South Africa (1940).

Rayleigh, Lord, Proc. Roy. Soc., A, 144, 266 (1934).

- Hudson, D. R., J. Phys. Chem., 49, 483 (1945)

'Hudson, D. R., Nature, 153, 562 (1944).

\section{FORTHCOMING EVENTS}

(Meetings marked with an asterisk * are open to the public)

Monday, February 23

INSTITUTION OF ELECTRICAL ENGINEERS (at Savoy Place, Victoria Embankment, London, W.C.2), at 5.30 p.m.-Discussion on "Corrosion in Electrical Apparatus" (to be opened by Brigadier F. H. Maclennan). INSTITUTION OF THE RUBBER INDUSTRY, MANCHESTER SECTION (at the Engineers" Club, Albert Square, Manchester), at 6.15 p.m.-
Mr. L. A. Oliver: "Machinery and Layout in German Rubber Plants".

Tuesday, February 24

UNIVRRSITY CoLLEGR LONDON (in the Anatomy Theatre, Gower Street, London, W.C.1), at 1.15 p.m.- Prof. Daryll Forde : "Anthropological Analysis of Social Change;"*

ILLUMTNATing ENGINEERING Societr (at the Lighting Service Bureau, 2 Savoy Hill, London, W.C.2), at 6 p.m.-Discussion "That Artificial Lighting is an Adequate Substitute for Natural Lighting".

SOCIETY OF INSTRUMENT TECHNOLOGY (at the Roval Society of Tropical Medicine and Hygiene, Manson House, 26 Portland "Tace, London, W.1), at 6.30 p.m.-Dr. H. W.

TEXTILE INSTITUTE (joint meeting with the MANOHESTER GEOGRAPHICAL SOCIETY, in the Geographical Hall, St. Mary's Parsonage Manchester), at 6.30 p.m.-Mr. F. Shuttleworth: "Some Strange Native Customs and Ways of Using Textile Materials".

Chemical Societr, Society OF Chemical INDUSTRY, and ROYaI INSTYTUTE OF CHEMISTRY, EDINBURGH AND EAST OF SOOTLAND SECTIONS (joint meeting with the EDINBURGH UNIVERSITY CHEMICAI SocIFTY, in the Biochemistry Lecture Theatre, Teviot Place, Edin burgh), at 7 p.m.-Prof. W. F. K. Wynne Jones: "Proton Transfer and Analogous Reactions".

INSTITUTION OF ELECTRICAL ENGINEERS, LONDON STUDFNTS' SECTION (at Savoy Place, Victoria Embankment, London, W.C.2), at 7 p.m.-Mr. P. Good: "The General Aspects of Standardization" (Presidential Address).

SOCIETY OF DYERS AND Colodrists, SCOTTISH SECTION (at St. Enoch Hotel, Glasgow), at 7 p.m.-Mr. E. Marney : "All-over Pigment Coloration of Textiles".

ROYAL INSTITUTE OF CHEMISTRY, LONDON AND SOUTH-EASTFRI CounTIES SECTION (at the Cherry Tree, Welwyn Garden City), at 8 p.m.-Prof. D. H. Hey : "Reactions of Benzoyl Peroxide".

\section{Wednesday, February 25}

Royar Socretry of ArTs (at John Adam Street, Adelphi, London, W.C.2), at 2.30 p.m.-Mr. C. Butement: "Three-Dimensional Photography'.

Royal Mioroscopicat Society, Section of IndUstrial MicroscopY (in the Hastings Hall, B.M.A. House, Tavistock Square, London, SCOPY (in the Hastings Hill, B.M.A. House, "The Structure of the Skin W.C.1), at 5.30 p.m.--Miss

SOCIETY For VISITING ScIENTISTS (at 5 old Burlington Street, London, W.1), at 7.30 p.m.-Discussion on "The Growing Points in Science, 2. (To be opened by Prof. A. A. Hall and Prof. C. H. Waddington, F.R.S.)

\section{Thursday, February 26}

Royal SocIETY (at Burlington House, Piccadilly, London, W.1), at 4.30 p.m.-Sir Wallace Akers: "The Research' Laboratories of the Imperial Chemical Industries, Ltd."

LINNEAN SOCIRTY of LONDON (at Burlington House, Piccadilly London, W.1), at 5 p.m. - Exhibition Meeting (Exhibits of botanica and zoological interest, with brief comments by the Exhibitors). 